\title{
㸚室內 氣流の模型實驗
}

(小學校計畫江於ける衞生的建燢施設の湖究)

正員伊藤正文.

\section{丙 容 福 慨}

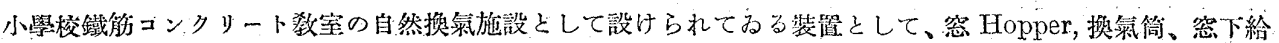
氣孔及び廊下側出入口下部無双口の夫々を適宜に組合せて生ずる種々の等内氮流の性狀を知るために、縮尺1/10

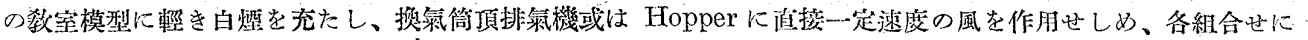
よつて生ずる氣流の動態を筫驗觀察したものである。

$$
\text { \% }
$$

\section{目次}

I. 序 言

II. 筫驗方法

(1) 實驗装置

(2) 䨘驗の手順

(3) 蘡瞼氮流の欟察と撮影

III. 實臉結果

IV. 考按

V. 綜 括

\section{I. 序}

所謂學校換氣の問題は、現在では䇪內氣候條件の調整 を目標とし處置としては自然換氣法とその補助施設とを 以て充分であるとする說に傾き、之に關する䂰究凟料も 牧舉に遑ない程であるが、自然換氣による室内氣候調整 の主要條件である氣流の動態に關しては未だ適確なる知 見を得られず、從つて檢窈を要与る㫮が多いのを痛感す

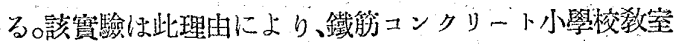

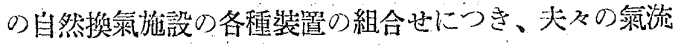
の動態を呚窒模型によつて觀察するるを目的とする。更に

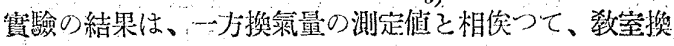

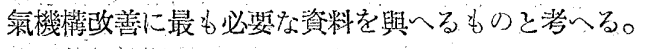

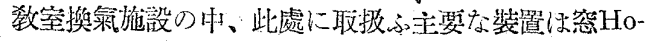

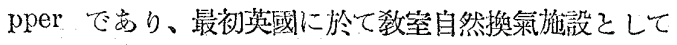
工夫䁈施され、學童衛生上好成績を示したと云はれてる る。しかしながら此留置によつて如何なる氣流動熊を星 するかは、末推測の籍園を出でず更に的確な資料がな い。

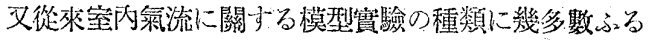
ことが出來るが、その方法を大別すれば、煙草、線䅛等

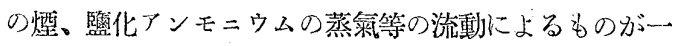
つ、氮流に代方るに水流等の液體の流動を以てしその哭 况を推知するものつ二つでする。此他筫際の敉室に於け る氣流分布の實測法としては、栭船或は煭紙の小旗の動

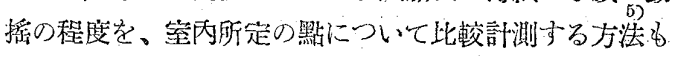
用ひられた。小旗の動摇程度によつて觀察するる方法で は、室內を敖層の水平面に分つて、各層の動態を觀察し

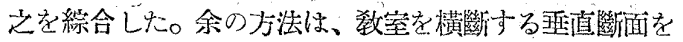
光幕によつて 3 ア所に設定し、夫ふの二次元的動態を觀

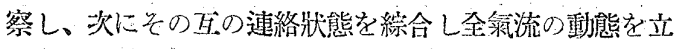
體的に認識し得る樣なす針を取つた。

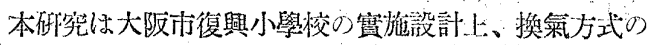

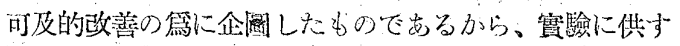
る償型其他之に附随与る條件は該市訢害の規模を標集と したものであることを附言して置く。

1) 大阪市技阿。

2) N.Y.C.V. "Ventilation, Report of the New York State Commission Ventilation", Sir Felix Clay,

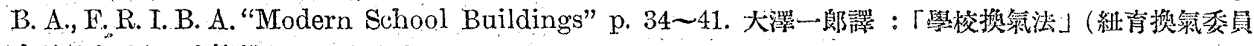
會最終報盗)、建築稚誌、昭和 8.2 。

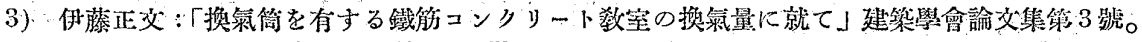

4）英國に於ては Dr. Ried が建築家 F. Hutchings と拹カして 1907 年烚めて Staffordshire の、Darlaston の學校に Hopper を設け、1910 年には Widdow によつて Derbyshire の North Wingate School に、 後には Southend-on-seaの學棱でも教室の兩側を空として通氮すること、空。出入口部に Hopper inlet が設けられた。—Sir Felix Clay：前揭著珰。

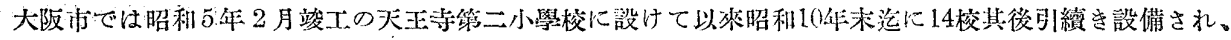
父改良されつっある。

5) N. Y. C. V.: 前揭著書, p. $4 \tilde{0} 2 \sim 468$ 。 


\section{II. 實驗方 法}

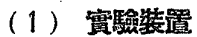

（a）模型は大阪市復興小學校教室の標淮矩㖕に準じ、 縮尺 $1 / 10$ にと、杜、梁、空下、床等の主要骨組をべ二 ア板で組立て、塗板面に相當する壁面、天机面、及び營 Hopper をセロフアン紙にて張り轅園及上部からの觀察 並に寫椇撮影、之に伴ふ照光に便ならしめた。

模型室の氯積約 $0.17 \mathrm{~m}^{3}$, 廊下侧下部給氣孔の大きさ $4 \mathrm{~cm} \times 25 \mathrm{~cm}$ ，換氣筒面排縠孔の大きさ $2.5 \mathrm{~cm} \times 7 \mathrm{~cm}$, Hopper 開口部面積凡そ $1.5 \mathrm{~cm} \times 25 \mathrm{~cm}$ ，でむる。

換氣筒は、模型が 3 階敉室に該當する割合の高さに設 け、筒頂の排氣機は從來の校舍に實施されてるる型式 4 種を同じくセロフアン紙で製作し、T.K. X.Cの等號を つけた。之等は隨洔取換いられる樣にし、一定風速に於 て排氣力を此較した處、Kが最も效果大でむることを認

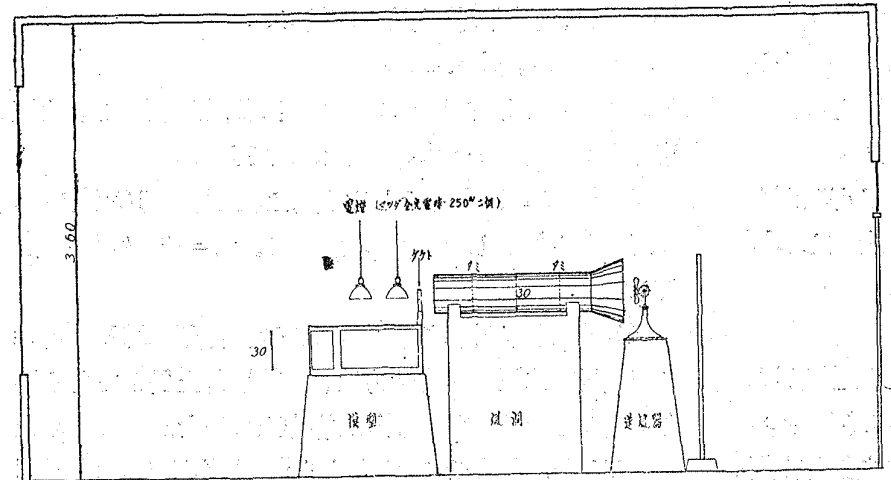

第 1 圖 (A) 模型配置及琠驗空見取團

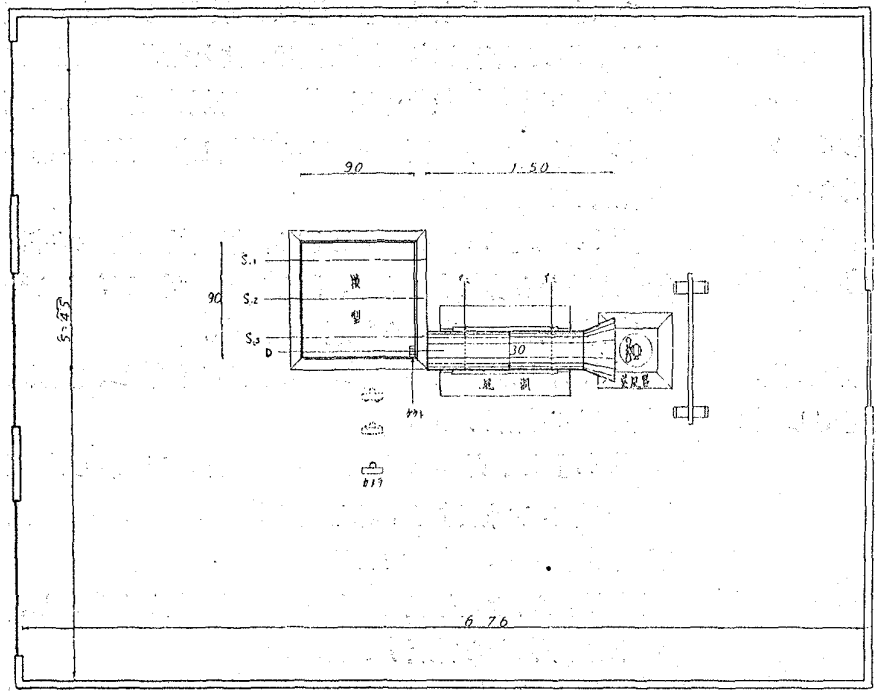

第 1 圖 (B) 同上平面圖
め、㙰驗には K 型排州機を用ふることに決定した。

又 Hopper は、午の位置に上る氣流變化を觀るた め、すべての空の部分に上中下 3 段に設け、夫及約 $2 !^{\circ}$

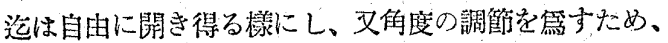

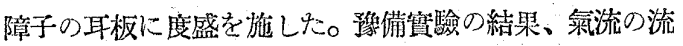
入動態を觀るに最る都合是しそ認めらるつ開伯 $10^{\circ}$ を實 驗の條件として規定した。

(b). 風洞は、武力製圓筒とし徑 $30 \mathrm{~cm}$ 長さ $125 \mathrm{~cm}$ 筒內に細疎 2 枚の銅檕銅を任意に取付け得る樣にして風速

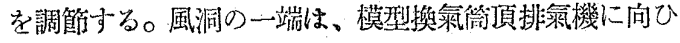
一端は添風器に面寸当漛設備する。

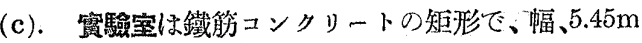
奥行 $6.76 \mathrm{~m}$ 高さ $3.60 \mathrm{~m}$ の一室で一端に上下空 3 ケ所、他 の一端に片閵屝出大口 1 ヶ所がむり、多んど完全に締切 ることが出來る。空內中央に模型、風洞、搨風機及び訅

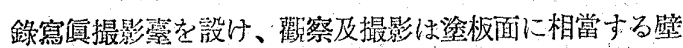

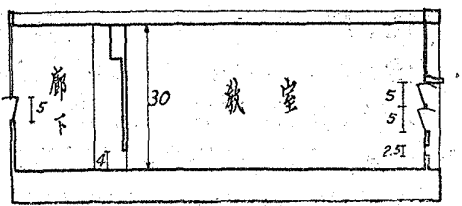

スリット No. 1 (S. 1)

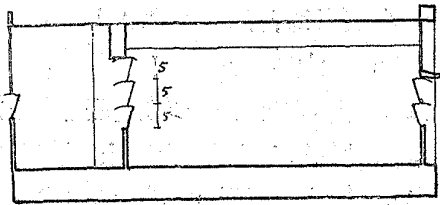

スリット No. 2 (S. 1)

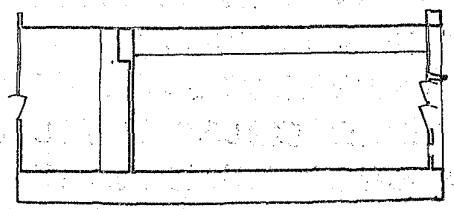

スリット No. 3 (S. 1)

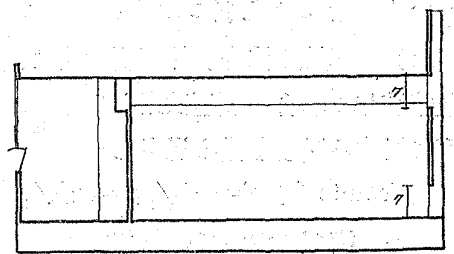

換雨筒を合专切斷面 (D)

第 2 圖 各スリッ卜衒面及末ッ 跴配置圖

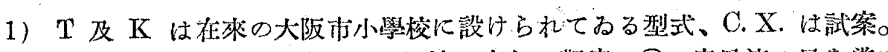

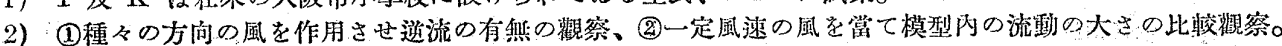

3) 三菱製艾流27ワット 60 サイクル。 


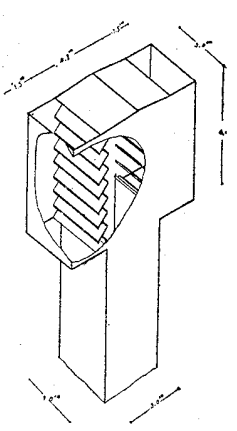

K 型

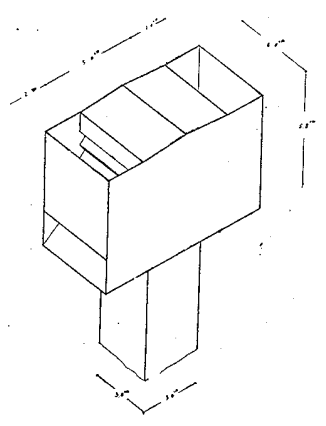

$\mathbf{T}$ 型

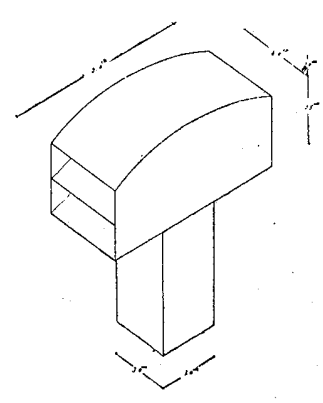

C 型

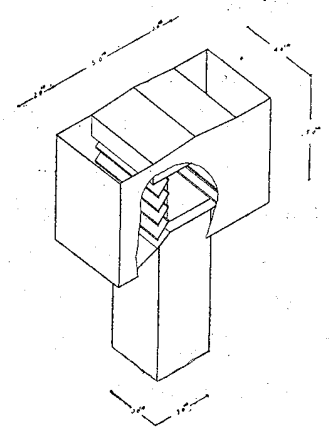

$\mathrm{X}$ 型

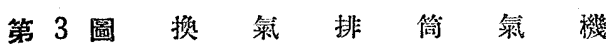

面を通してする樣に設備しな。

(d). 實驗用の白煙は、最初冷却した煙草の㖶と線漕 の煙と、欖化アンモニウムの蒸氣とを同時に發生し相當 の大きさのマイェルに充たして酮置し、白煙の沈下゙を此 慗した處、線香の煙が最も長く濃度の均等を保も得るこ そを確め。實驗には此香煙を用ゆるこそ〉した。

(e). 模型室肉外の溫度を近似の状態にする必琶があ るため、模型の內外に寒暧計を㲘吊して温度を檢し、 $20 \mathrm{~F}$ 迄の溫度差は許容することつした。

\section{（2）實驗の手順}

(a). 煙の發生、先づ模型底部から澄入した香煙が冭 萠し、充分擴散し且殆んど静止の狀態に達する時を街つ。

(b). 照光、模型の天井版の 3 师の各中央部を横斷 する $2 \mathrm{~cm}$ 幅の探光スリットを作る。郎ちセロフアン版 の上にスリットを切拔いを厚い黑色紙を覆ひ、スリット の直上 $30 \mathrm{~cm}$ の高さに 250 ワットの寫傎電球（反射笠 付） 2 燈を腕木にて交へ、之を3所の並行のスリットの 直上に自由に移動し得る樣に裴置して。斯くしてスり トから射大する光が。模型內に生ずる光幕に現はれる氣 流の動態を觀る。此場合、背壁面に近い樑間のスリット を S.1，中央梁間のbのを S.2, 塗板面 (手前の壁) に 近いるのを S.3 と名づける。

(c). 風速の決定、此模型賽驗は、真力の作用に依る 氣體流動の場合の類型法則から Froude 獤を適用し、模 型に跱する風速を豫め規定した。

Froude 數 $F=w_{1} / \sqrt{g l_{1}}=w_{2} / \sqrt{g l_{2}}$

$w_{1}:$ 模型についての氣流速度

$w_{2}:$ 䆵物についての粬流速度

$l_{1}:$ 模型についてての寸法

$l_{2}:$ 實物についての寸法

模型は $1 / 10$ の縮过で岕るから

$w_{1} / w_{2}=\sqrt{l_{1} / l_{2}}=\sqrt{1} /{ }_{10}=0.317$

$\therefore \quad w_{1}=w_{2} \times 0.317$
印ち模型に作用する風速は䁈際の風速の約 $1 / 3$ に相當す

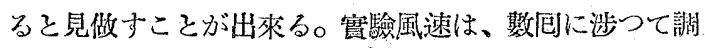
節の結果、模型の換氣筒頂に於て。 $w_{1}=62 \mathrm{~m} / \mathrm{min} \div 1 \mathrm{~m} / \mathrm{sec}$

そ定めた。即ち約 $3 \mathrm{~m} / \mathrm{sec} の$ 賽際の風速に相當し、大阪 甫の平均風速 $2.73 \mathrm{~m} / \mathrm{sec}$ に近い值である。

义 Hopper に作用せしめる風は、風洞を用ひず、1.8m の距離から湥風し Hopper 前にて、 $w_{1}=43 \mathrm{~m} / \mathrm{min}$ の風 そした。

(d). 給氣及排氣各留置の組合せ、及實驗順序。給排

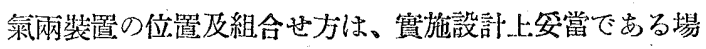
合を撰摆した。又實驗順序は、繰作上の便を計つて定めた に過ぎない。組合せは[C. I]から [C.X]迄10種。[C.IX] はHopper の位置の組合せ6 種に別けたため、實驗組

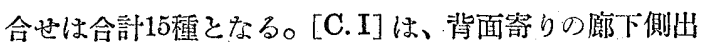
大口障子の腰下部に無双口を設け、之と對角線の位置に 設けられてるる换氮筒以床に接する排氣孔を開いて通氣

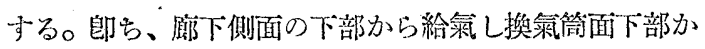
ら排氣する方式である。

[C. II] は [C. I] の變化として、換氣筒壁面の天批に 近い上部から排氣与るもの、郎ち廊下側面の下部から給 氡し、換氣筒面上部から排䓙する方式。

[C. III] は外侧空 Hopperの中段から給氣し、換氯偷 面下部加排㯒するもの。

[C.IV]は、外側空 Hopper の下段から給䓙し、換氣 箈面下部から排氣する。郎ち [C. III] の Hopper の上. 下の位置を撸へ㤂ものである。

[C. V] は、腒下側中代切Hopper 上段から給氯し、 換氣筒面下部から排氣する場合。

[C.VI] は、外側空 Hopper 中段及び廊下側中仕切 營 Hopper 上段より給氮し、換氣筒面下部から排筷す る場合。

[C. VII] は、[C. VI] の給燓 Hopper を。廊下僛の

1) Ludwig Schiller: "Hydro und Aero Dynamik" (Handbuch der Experimental Physik) p. 220. 
上段の代りに中段を用ゆる場合。

[C.VIII] は。廊下側Hopper 上段及び廊下側出入口 下部から給氮し、換氯筒面下部から排氣するもの。

[C.IX]は、外側及び裙下侧の相對する Hopper各段 の組合せにより通埭する 6 種の場合。但し、外側空から 流大し中仕切空へ流出する。㕛外侧空 Hopper は、賀施 矩計に於ては遮光廂以下の位置に設けられる都合上上段 は必要がない。
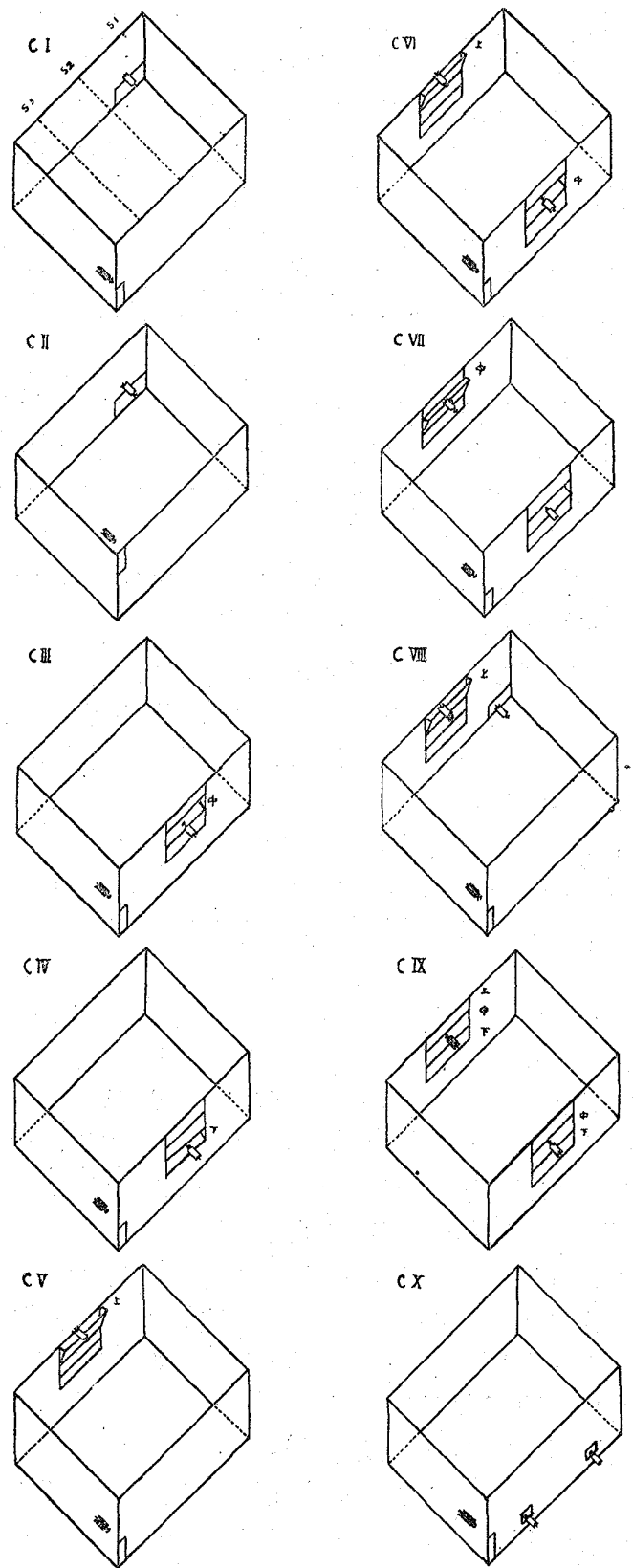

第 4 圖通氣裝置組合せ及配置圖
各 Hopper の組合せ順序は次の通である。

No. 1 中段 Hopper から上段 Hopper へ、

No. 2 中段 " " 中段 " "

No. 3 中段 " " 下段 " "

No. 4 下段”" 上段 " $"$

No. 5 下段 " 中段 " "

No. 6 下段 " "下段，" "

[C. X] は、外側空下 2 所の給氯孔から流入し換氣 䈪面下部から排氮する場合。

以上15通であるが、此等の中、廊下側を開く場合には、 郎下外例の Hopper を開解 $15^{\circ}$ に全部開いて置く。

（3）演駼攻流の觀察と撮影

模型空に煙を充たし、天井のスッットから照光し、所 要の組合せの換氣孔を開き風を與へると、瓮入した透明

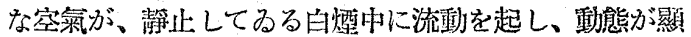
著に觀察出來る。之を斯包宛絽返し、大體流動の傾向が 一定する狀態を見て之を撮影した。

\section{III. 實驗結果}

此處に赤告する實驗の結果は、昭和11年6月21日から 同7月24日までの期間に行つるものでもる。以下各博置 の組合せ得に順を逐つて、氡流の動態につき觀察しな結 果を記述する。

[C. I]

廊下僛出入口下部から排臽筒面下部への通策。風が作

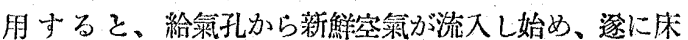
面に底流を作る。主流の部分は給氯孔の面に直角の方向 に略孔の高さを保つて林面を逐つて進儿でるる。此流と

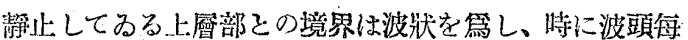
に渦夋を作り美しい Scroll 狀を呈する。此底流は、主 流方向の外に床面全體に涉つて給策孔から排氮孔に向つ て流れる。更に备スリット每に觀察する。

S.1 背面に近い梁間のスリット S.1 では、廊下側下 部から流入しな主流を第す底流が、對側面に當つて上向 し更に天仨に當り又韩流して天背面に這ひ給率孔上部の 壁面に賞つて下降し、一部は給篓孔からの流入氣流に然 込まれ、一部は珮をなして消光る。郎ちS.1の主流は林 と天井とを廻る很摆氣流であつて、底流から壁面を上舁 する迄の流が、特心著明である。

S. 2 底流が對側に當り憵に沿つて排氯孔の 方向郎ち S. 3 に向ふ僛流が一つ。 S.1 の循環氣流の天判面から梁 下を潜つて S. 2 の天井面を流れ S. 1 と同方向の循環を なすが微弱なのでS.10樣に著明でないもの〉二つが女 る。之等の底部には S.1 から挑氯孔に问ふ底流がをり、 各氣流の接解面では互に洞流を生じて擴散してるる。

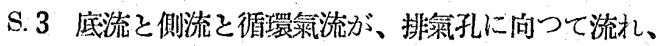

1）大阪市在䧒小學校の型式。

2) 䳆眞機: Contax. F. 28 開放、Time $1 / 5$ 秒。 
排氮孔附近の檠面に當つて上万又は科上方に轉流された 打面に向つて浯流を描く。循環氯流は崩れて動熊は顯著 な方向を示さない換氮筒の引きが弱い場合は、S.1, S. 2

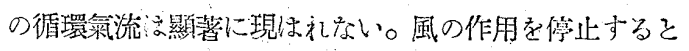
流動が止る。

[C. II]

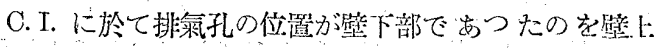
部に設けな場合で岕る。

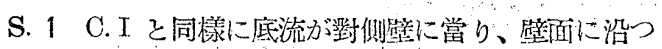

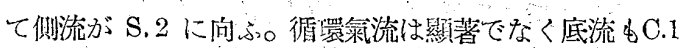
程强くない。

S. 2 S. 1からS.3の排氯孔に向ふ側流が主であり、S.1 の天捌ら梁下を潜り S. 2 に入つた流が、側流に押さ れつつ循環の傾向を示すが明膫ではない。底流子微弱な がら換埭筒の方向に流れてるる。

S. 3 侧流が排氯孔に入り、附近から轉流した部分は渦 流を作る。又S.3 の中心部から排氮孔に向つて曼引され

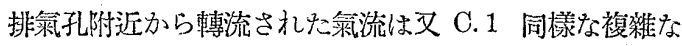
渦流を生ずる。

[C. III]

外側空の中段 Hopper から給氮して壁下部排氯孔から 換氣筒へ流出するタので、此場合は S. 2 の部分で觀察

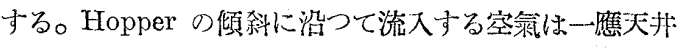
面に當つて瀜流堂しつ今掌中央部に向つて下る。但し

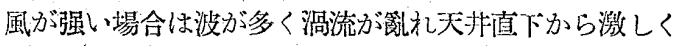
拱散する。主流は排氣孔に向ふ底流に爷込まれる。

[C. IV]

C. III に於けるHopper の下段から給姚するもので氯 流の動態は C. III と殆儿ど同樣であり、天北面から下

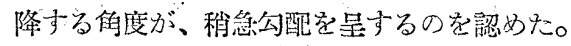

[C. V]

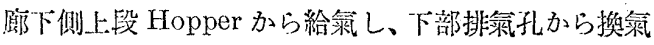
筒によつて排氯する場合である。流入空氮はHopperの 傾斜に沿つて天愐に當り渦流ななしつ、天北面に沿ひ

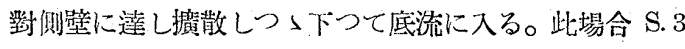

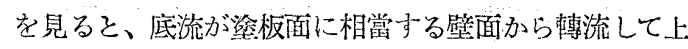

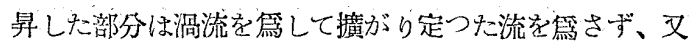
底流に引加犸て排埭孔に入る。

[C. VI]

廊下側上段 Hopper と、外侧空中段 Hopper から給 筷し換氣箱面壁下排氣孔から流出せしめる場合である。

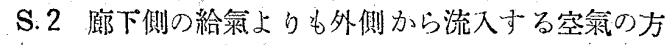
が一般に多量である。外側 Hopper からその倾斜に沿 つて流入した空氮は天讲面に趞してゆるく轉流し科下方

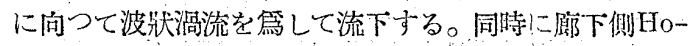
pper から流入して空氣は天井面に沿ふてて淮み、下向し 流が大きく然上げて來るのと合して部分的に環狀氣流 を生じ、徐々に床面の底流に引か记て流出する。
S.3 環状の氣流が少しづ〉崩れてはS.3の中心部に 向ひ更に科に排氣孔へ向ふ。剩つて轉流した流は不定な 洞流を生ででる。

[C. VII]

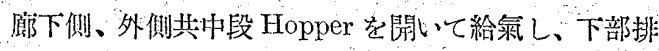
氣孔から換氮筒によつて排氣するものでむる。

S.2 Hopper に沿つて天井に向つた氣流は、スリ\% トの中軓に向つて殆んど左右均齊の珮流となつて淮み、 中軸棠で相合ひ共に押合ひつ」轉流し下向し徐从に擴散 して底流になる。流入した氣流の相方の力が均衡しない 時は、强い方が科に下向し、弱い万が上部を淮久 C.VI の場合と同じ動態となる。特に一方が弱い場合は（多く

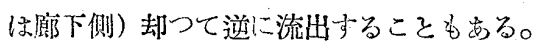

S. 3 S. 2 .の中軸で二つの渂流に押された部分が S. 3 の中心部に流れ轉じて斜に排氯孔に向つて流れる。壁面 に當つて轉流した渦流の狀態は C.VI と同樣である。

[C. VIII]

榔下側下部無双口と同侧 Hopper 上段から給氣し下部 排氣孔から換氮筒へ排氮する。此場合はHopper が上段 であつても下段であつて方殆んど戀りないから上段を開 いて觀察したものである。

S. 1 無双口から人つた底流が C.I. の場合と殆んど同 樣な埭流を起す。

S. 2 底流は C.I そ同樣であるが、Hopper から入り 一度天邦に當つて氣流はS.10天粄ら梁下を潜つて來 る很環氣流に押されて直下に下降する傾向を示し底流に 叁込まれてゆく。

S. 3 C.I の S.3 と同樣の動態を示す。

此組合に於ては、S.1の底流が强、特には、Hopper か ら逆に流出し殷下に渦動を起すことがする。

[C. IX]

外側中段又は下段 H opper から給氣し、嫏下側の上 中下゙各 Hopper から排氮する6 種の組合せである。此 等の動態から全般に Hopper 氣流の性質を䚐知し得る と考へる。觀察はすべてS. 2 に於て行つた。又此組合せ はすべて風洞を用びず直接 Hopper に微風を當てな。

\section{No.1. 中段から上段への通氮}

Hopper に沿つて流入し天井面に虽り洞流をなしつ〉 天井面を流れ劉侧上段Ho per から流出する。流出し切 れない部分は渦を描きつ」主流へ毁る。風が典風に近い 時は、天片面の通氯の久が見的る。

\section{No. 2. 中段から中段への通氣}

Hopper に向つて流入し天井面を這ひつ〉描く渦流が No. 1 の場合よりも大きく顯著になり、天州面に珜する

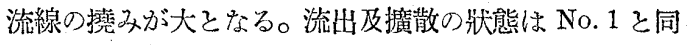
樣である。

No. 3. 中段から下段への通氮

No.2の場合よりも珮が大きく流線の罰みが大となり。 
滆流の底部が休に近づく。

\section{No 4. 下段から上段への通㢞}

Hopper に沿つて入つた空埭は天扑面に當り直に下向 に描く瀜が、前者の場合よりも大となる。即ち渦流が空 際の床近く下り更に對側の Hopper 几淮む。

\section{No. 5. 下段から中段への垿氣}

No. 4 と殆儿ど同樣である。

\section{No. 6. 下段から下段への通氮}

No.4 と殆儿ど同樣で㟧るが、流出寸る際 Hopper そ 床との附近に大きい洞老生じ床者逆行しつつ茶上る。

[C. X]

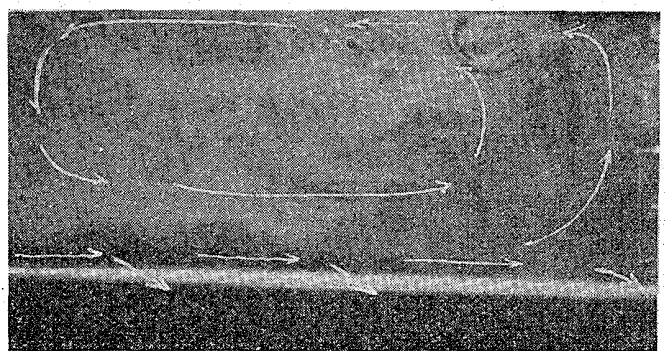

S. 1

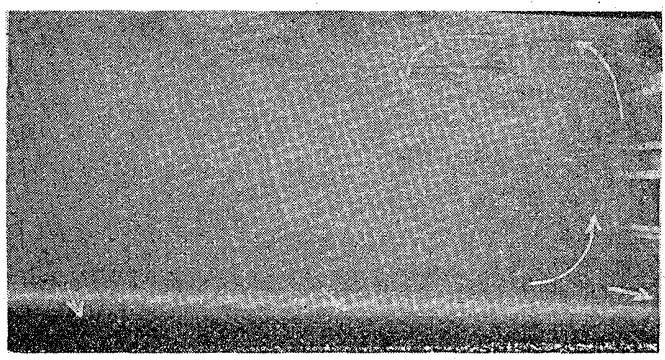

S. 2

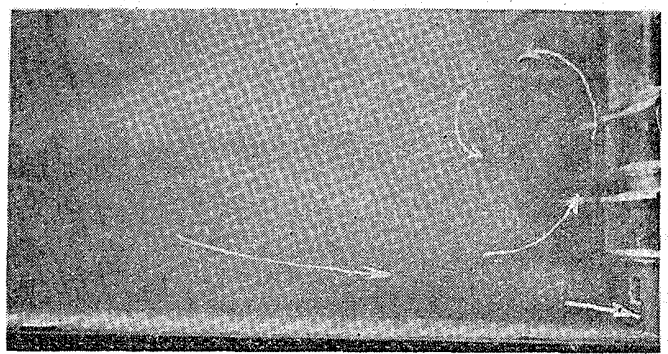

S. 3

第 5 圖 組合せ [C. I] の場合—S. $1,2,3$.

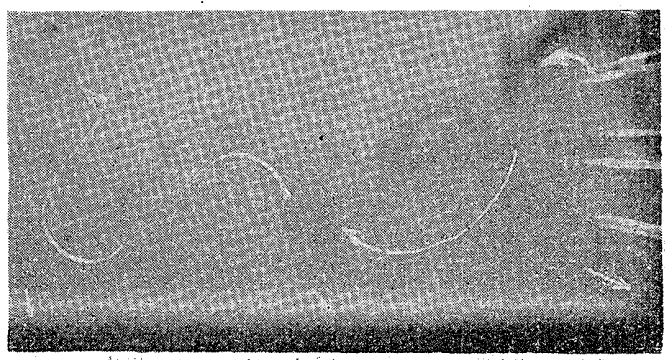

第6 圖 組合せ[C. III] の場合 - S. 2

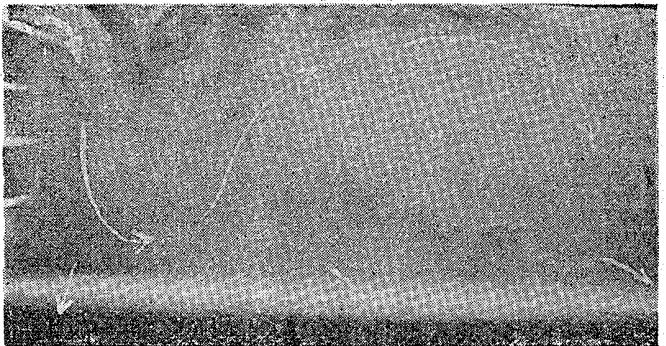

S. 2

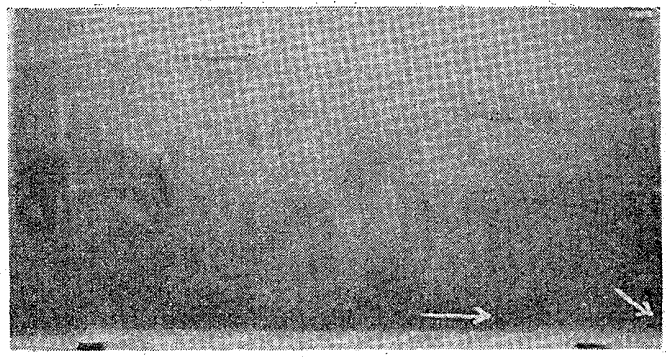

S. 3

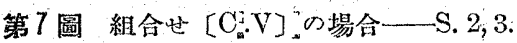

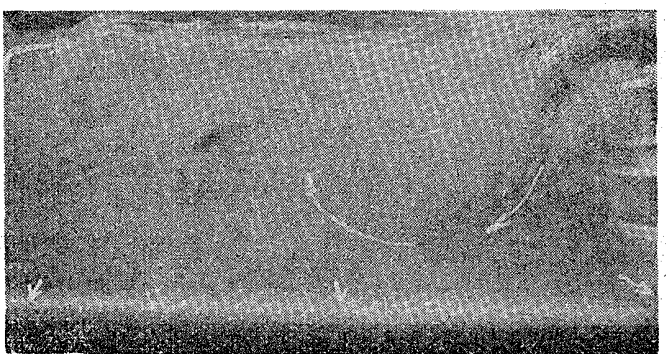

S. 2

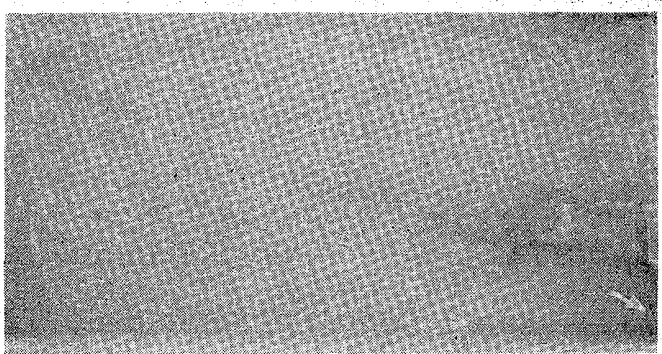

S. 3

第 8 圖組合也 [C. VI] 0 場合—S. $2,3$.

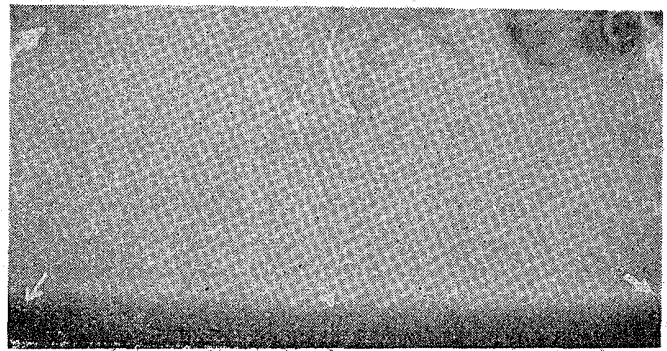

S. 2 


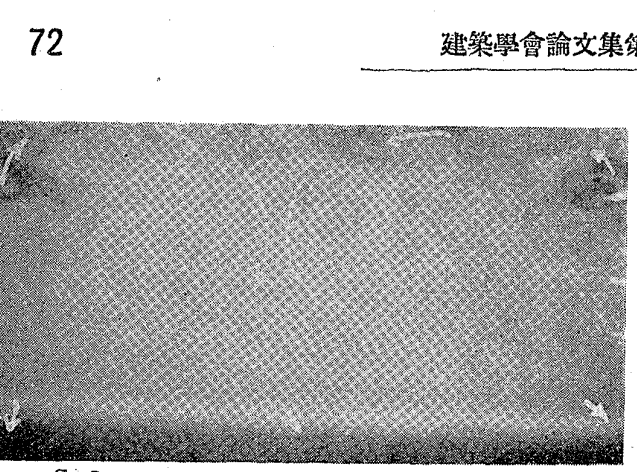

S. 2

第9圖 組合せ [C.VII] の場合—S. 2

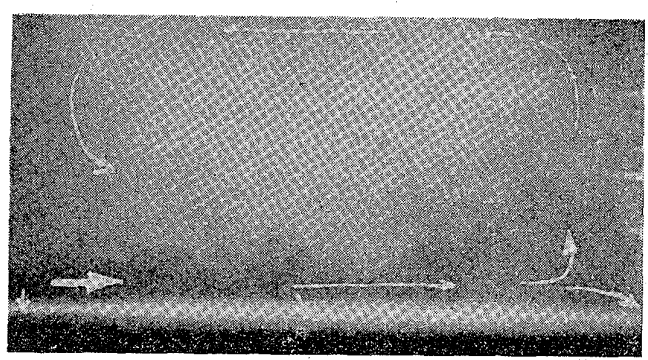

S. 1

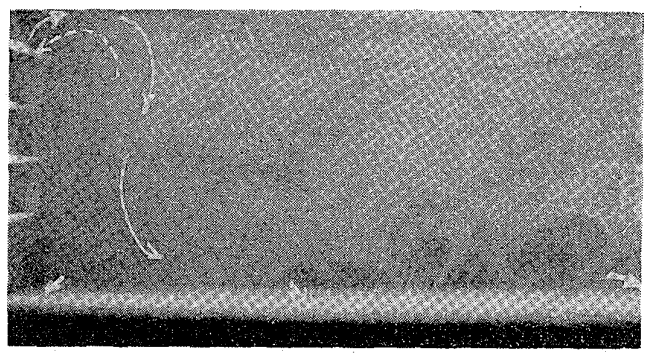

S. 2

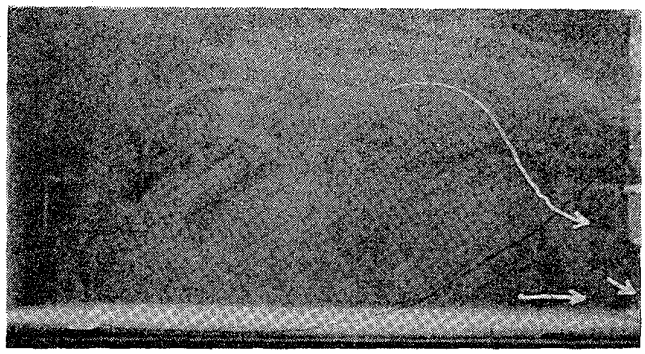

S. 3

第 10 圖 組合せ [C. VIII] 埸合一S. 1, 2, 3.

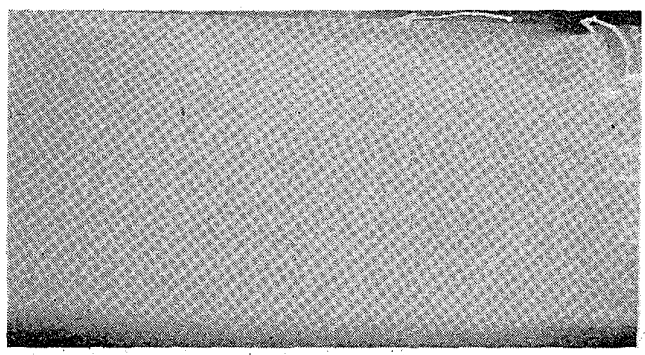

中段 $\rightarrow$ 上段

（殆ぞ無風に近い狀態）

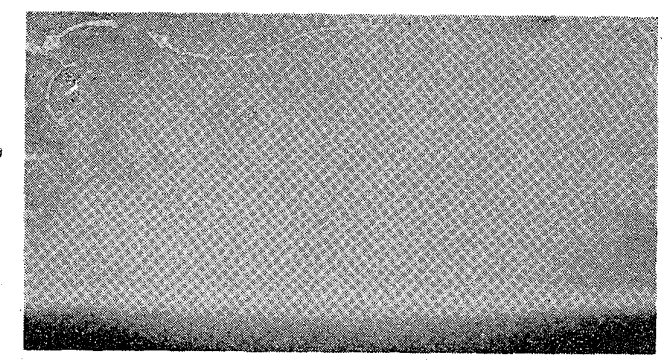

中段 $\rightarrow$ 上段

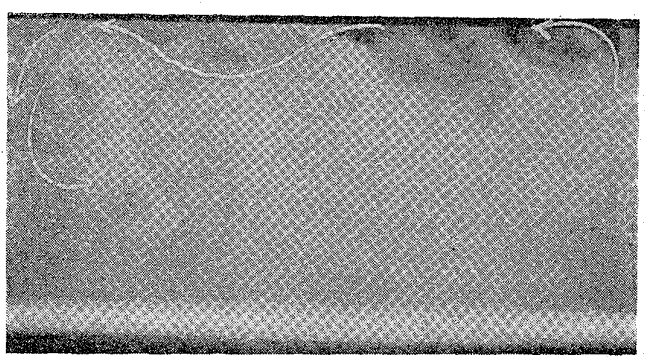

中段 $\rightarrow$ 中段

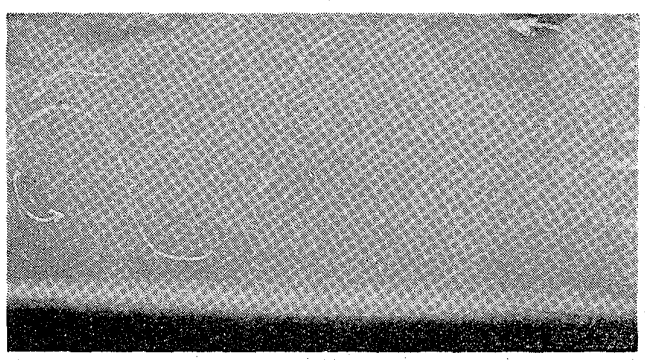

中段 $\rightarrow$ 下段

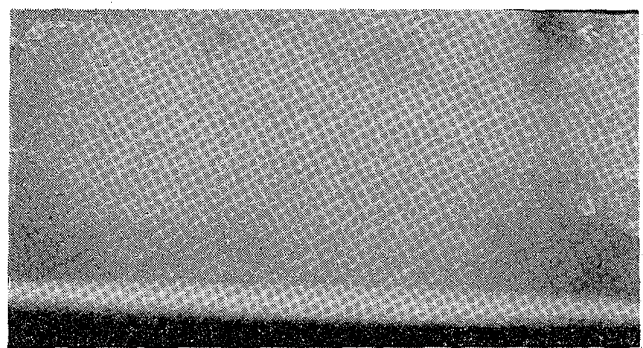

中段 $\rightarrow$ 上段

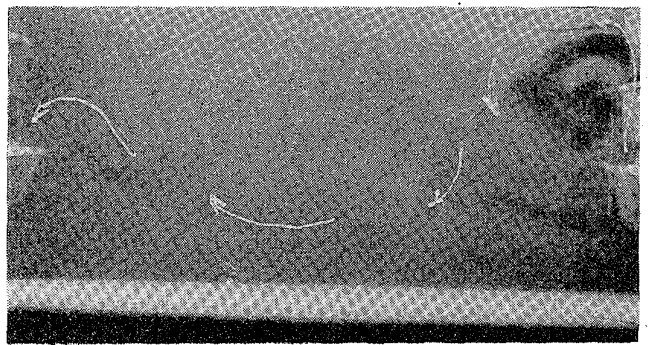

下段 $\rightarrow$ 下段

（殆ど勄風に近い狀態） 


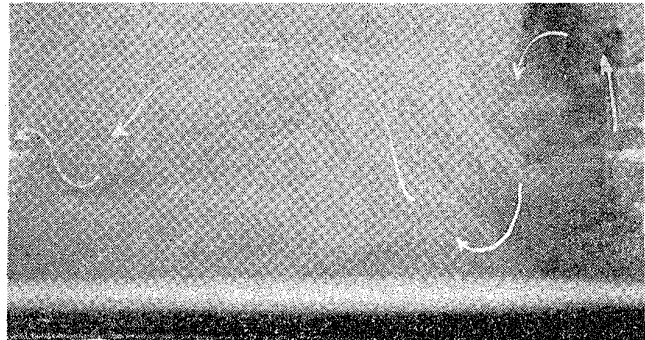

下段 $\rightarrow$ 下段

第 $\{1$ 圆組合せ [C.IX]の場合一S. 2.

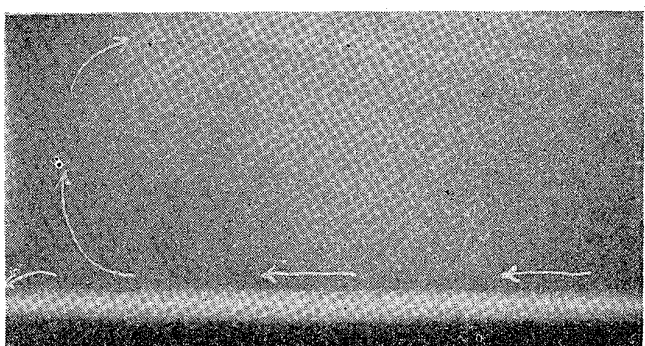

S. 1

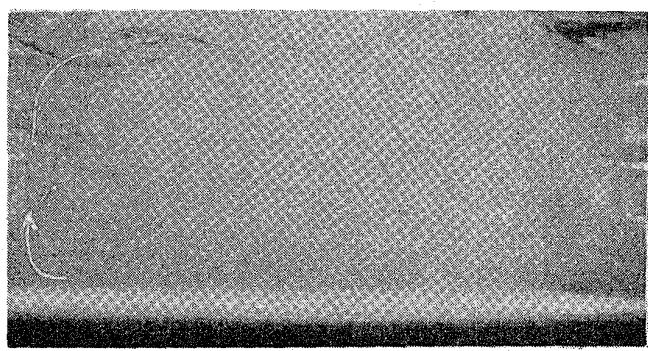

S. 2

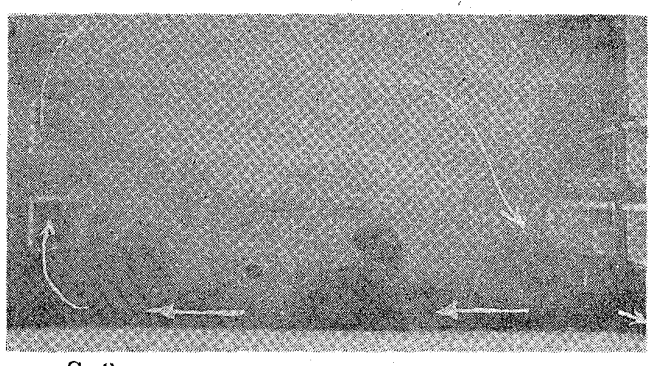

S. 3

第12圖組合世 [C.X]の埸合一S. 1, 2, 3.

外側空下 2 ケ所の給氣孔 (S. 1 及び S. 3 の位置に當る) から給氣し、換氣筒下部排䓙孔から流出せしめる場合で 声る。

S. 1 給氮孔から强く流入し主流は直進して對僛雚に 當り、壁に沿つて水本に轉流する。

S.2 S. 1 とS.3 とから壁下部に洎つて流孔る底流が 衝突して上昇し天井に澾しS.3の力向に擴が り流れる。 天井面では此等の流は緩漫で歞著に見えない。

S.3 S.3 の給氣孔から入る流の罵に休近い排氣埭流 は途中を遮斷されて動かず、S.2の上㸴部の流から斜に下
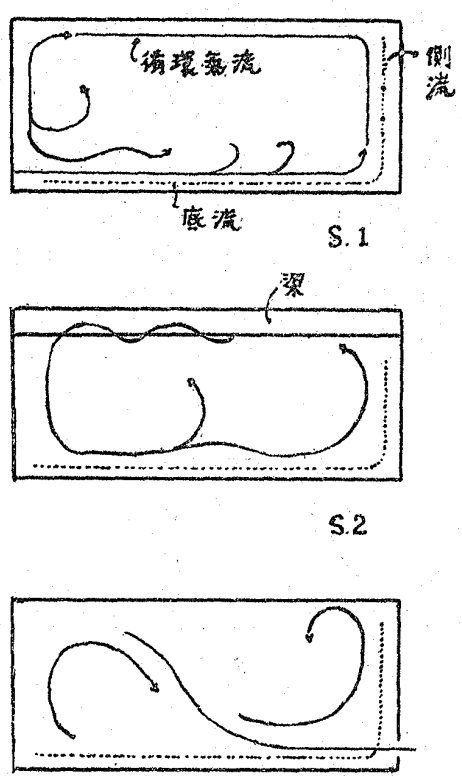

S. 3
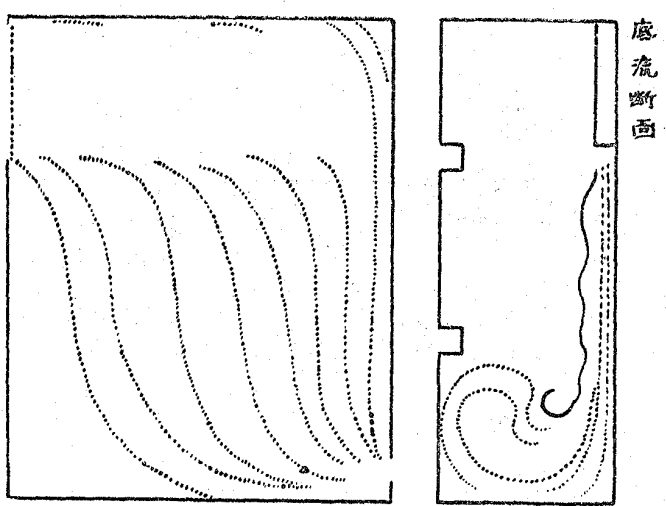

宦流平面。

第 13 圆組合せ C.I の氣流慟熊

向し排氣孔に入る、排鼠孔附近の壁に當つて轉流した部 分仿不定な洞流を生ずることは前の敷例と同樣である。

\section{IV 考按}

氯流の動態として換氣衛生上坐要な點は、すべての居 室者に比較的均等な微風を與へ、且つ所定限度以上の空 氣交換を衰鸟ことでむる。換言すれば、氯流動態の偏り

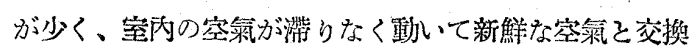
されててゆくことを理想とするわけである。

實驗の結果を見るに、從來行はれて來な給排氮孔の配 置組合せでは空壁或は天扑面休面に沿ふての久埭流の動

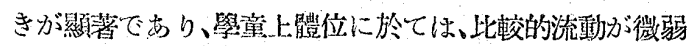
であることがわかつた。特に壁下部の給氣孔から流入す

1） N. Y.C. V. の最終報告に準ず札ば、學童 1 人につき1分間10立方吹を限度とする。 
る外氣は劃然とした底流を生し、冬季足許で寒冷を覺文 しめ床の麼埃を然上げ、呼吸水準面では换埭が不充分て あることが推知される。例へば O.I， C.X.如き場合て 屯る。 N.Y.C.V.の幾多の筫驗的研究に就て見ても、充 分に均等な氮流を得べき給排氣孔の配置方式が定つてみ ない。里竟、給筆及排氣沼比較的小さい面積の孔により て行はれる限り。交換空韱の總量は充分であつても、荎 內の位置によつて氯流の動態分有を異にし、均等な動き

\section{C 政}

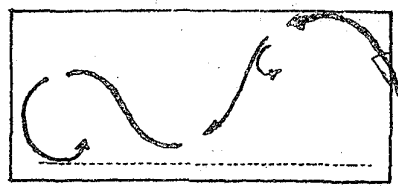

$C$.

5. 2

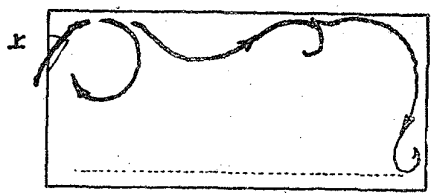

CP

5. 3

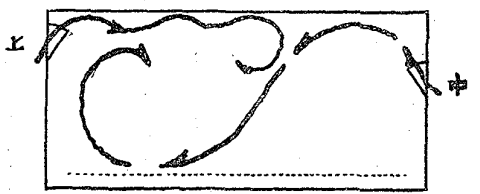

5.2
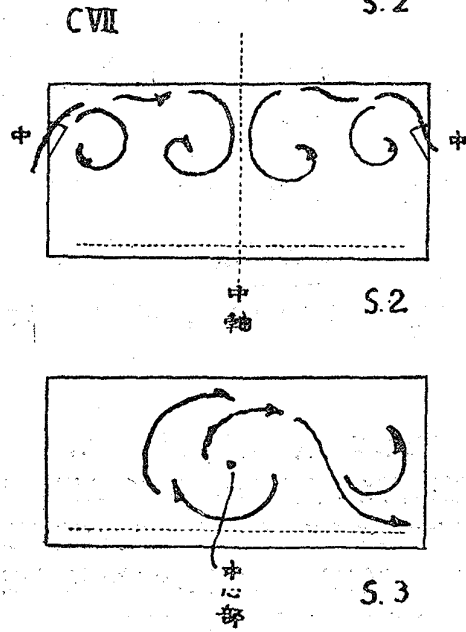

第14圖 Hopper から换㟈筒一の通埭

を得ることは困難であると考へる。

密 Hopper は此點に鑑みて設けられ、實施經驗の上に
學童生理上多大の効果を擧げたと云はれるが、之によつ

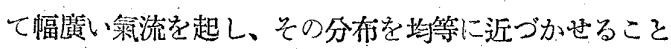
が出來る。しかしながら、Hopper の位置及組合せによ つては幾分睋風を感ぜしめる恐れがあり、或は定流を生 じて居公者汃滞在する部分は殆んど流動のない狀態にな ることがむる。Hopper は、外侧空及廊下側中仕切等

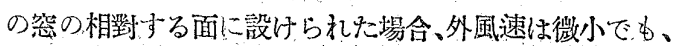

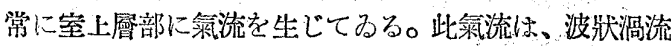
を第し、流入する方の Hopper が上位にもる程波が小さ

CIX

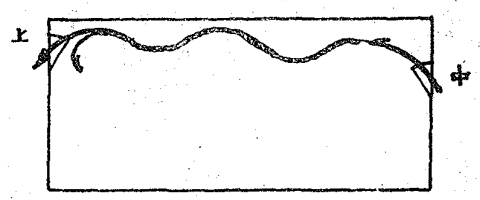

No 1

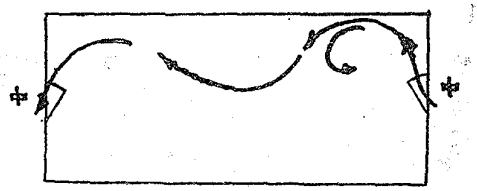

No 2

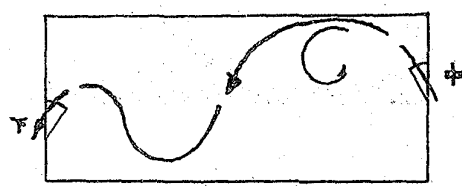

NO 3

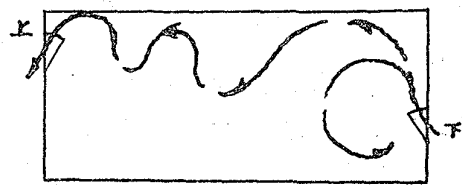

第 15 圖 Hopper の組合せによる通氮

くなり、全體としては上箇部のみを流れる。Hopper が 下位になると、波が大きく眯になり全體の流線が撓み下 つて來る傾向がある。又風速が大になる程。波の長さが 縮小し幅が大きくなる、郎ち流入空氮は速かに擴散され

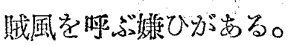

Hopper が上位にもる場合は、風速が大でも流入空氯 が激しく下降する傾问が少いが、Hopper が下位にむる 程㙌流が下降与る腺合は激しく不利になる。風速が極め て微小な時は、Hopper の位置が高い程上曆部に定流を 生じ、下部の動きは㱠んど無くなつて來る。此等を綜合

1) N. Y.C. V. : 前揭。

2) Sir Felix Clay : 前揭著暂。 
して考へると、中段 Hopper から中段 Hopper 几通氣 する方法が妥䓨であり、之を基碟條件として換氯筒との 組合せ等を考虑すべきであると思ふ。又 Hopperの開的 度が附加的な條件となること勿論でるる。

中段の Hopper を設借するとして、極めて微弱な外 風速しかない時には、換氣筒の排爫孔を關いて排氣すれ ば、C.VII に該當する組合せとなり、网僛 Ho 流入して下部へ撗散して排氯されるから好都合である。

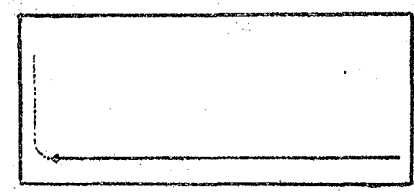

S.1

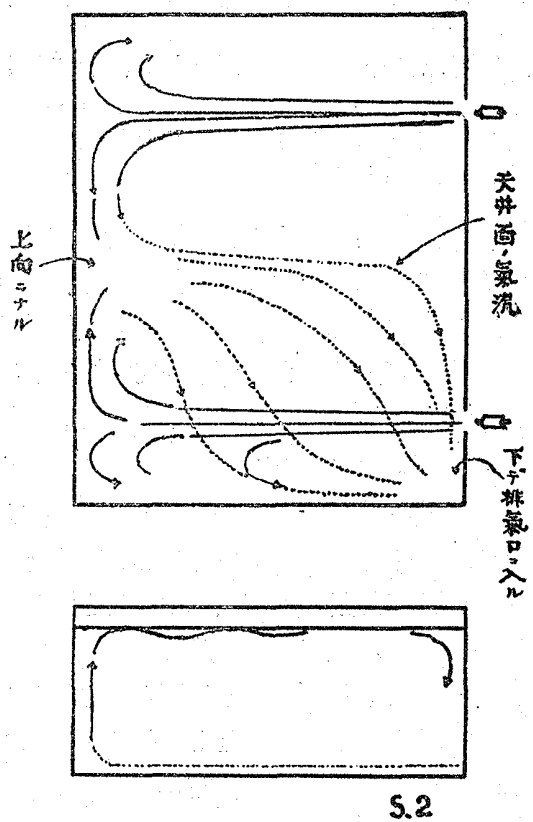

第 16 圖 組合せ C.X の氣流動驡

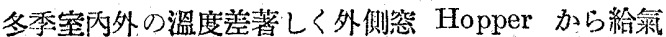
出來ぬ場合は、廊下側 Hopper の久を開き換氯筒によ つて排氯地しめる方式が適當である。

外側 Hopper から換雨筒詯く場合は、Hopper か ら流入し天井面から凡 $45^{\circ}$ の下方に向つて流れを生じ冬

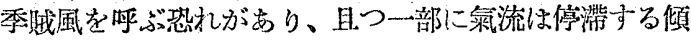
向があるので面白くない。之は C. III，C.IV に荄當す る。

C.VIII の如く、廊下側下部と同侧 Hopper そから給 氣するこそは床の底流の分が强いため Hopper が氮流に 方向を與へることが出來ず却つて Hopper から流出主 ることすらあり、Hopper を設ける意味を雹さない。

余の行つた $\mathrm{OO}_{2}$ 定量法に上る實際の敎公の換氣量の 測定は、所期の成績を示さなかつたが、换萧方式は本筫

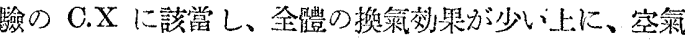
を换取した敉窒中央位置は流動微弱なため $\mathrm{CO}_{2}$ 量の變 化少く、從つてこの部分の掺氮量が少い結果を示したも のであるこそが明かになつた。

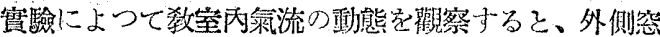

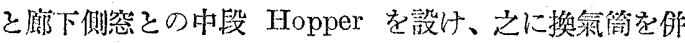
用ずることが、管當な自然換埭方式の一策であると考へ る。

V. 綜 括

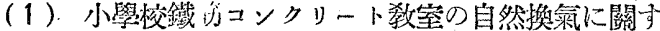

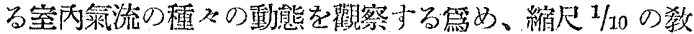
室模型による跑驗を試みた。

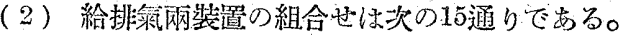

C. I. 換筱笠と榔下側下部給氣孔

C. II. 同 L

C. III. 換匊筒飞外㒋 Hopper

C.IV. 同 上

C.V. 換氮筒々廊下側 Hopper

C. VI。換氯筒々兩側の Hopper

C. VII. 同上

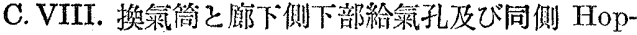
per

C.IX. 兩侧各 Hopper の組合ぬ 6 種

C.X. 換氣简と外侧塋下給氮孔 2 所

（3） C.I の主流は底流々側流及び周園面の循環嵊流 であつて、窒中央は流動極めて微弱である。C.IIは、C.I 々略同樣である。C.III, C.IV は唄流そ底流が主で天井 空側から床中央部への科線以上は流動微弱である。 O.V

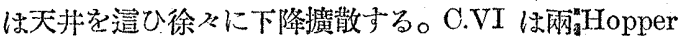

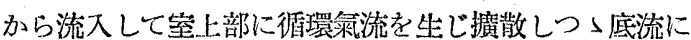
入り排氣される䳩に均等に近い、氣流分布起示す， C.VII は、C.IVと同檍に兩僛 Hopper から流入Lた空氯が中軸 部で對稱の洞流を生じ軸に沿つて共に下向し均等に搌散 する倾向を示す。C.VIIIは、廊下側下部からの底流が强 い舄に、Hopperの効果が少い。C.IXに於ては、Hopper の仿置が下である程氣流の波動が蹯になり、波が大きい

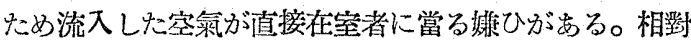
する上段の Hopper によつて生ずる氣流は、波が小さ く。天北面を这つて流出する。此等の中庸度を保つるの は相鄴する中段の Hopper であつて。践風を感ぜしめ ず均等に近い擴散を雼し、換氣が充分に行はれる。C.X

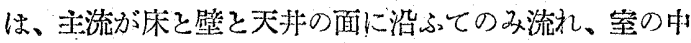
央部では極めて微弱な氯流しか認められない。

（4）以上の結果を綜合考察すると、相對する中段の Hopper そ换氮筒とを設け、Hopperによつて給氯し、排 埭はHopper 又は換氣筒による力式により氯像條件に應 じて理想に近い換氮效果を舉げ得らるっこと〉考へる。

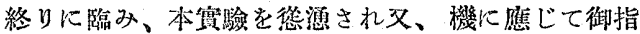

導下さつた家原博士に深謝の意を表する。

(昭相11年 9 月 1 日受附)

1）伊藤正文：前揭論文。 